\title{
Tomson Highway and Daniel Munduruku: Tricksterism and Literay Activism in the Americas
}

Rubelise da Cunha ${ }^{1}$

Submetido em 30 de abril e aprovado em 5 de maio de 2019.

\begin{abstract}
This article discusses Indigenous literary activism in the Americas. We address the defense of oral tradition proposed by Gerald Vizenor and Davi Kopenawa to focus on how literary writers Tomson Highway in The (Post) Mistress (2013) and Daniel Munduruku in Chronicles of São Paulo (2004) perform tricksterism as "wordmakers" that create new forms of expression for the empowerment of Indigenous traditions.
\end{abstract}

Key Words: Literary activism. Empowerment of Indigenois traditions. Highway. Munduruku.

Resumo: Este artigo discute o ativismo literário indígena nas Américas. Aborda-se a defesa da tradição oral proposta por Gerald Vizenor e Davi Kopenawa para analisar como os escritores literários Tomson Highway, em The (Post) Mistress (2013), e Daniel Munduruku, em Crônicas de São Paulo (2004), performam tricksterismo como "criadores de palavras" que criam novas formas de expressão para o empoderamento das tradições indígenas.

Palavras-chave: Ativismo literário. Empoderamento das tradições Indígenas. Highway. Munduruku.

We are touched into tribal being with words, made whole in the world with words and oratorical gestures.

Gerald Vizenor

This way these words will never disappear. They will always remain in our thought, even if the white people throw away the paper skins of this book in which they are drawn and even if the missionaries, who we call the people of Teosi, always call them lies.

Davi Kopenawa

As a Brazilian scholar with a mixed ancestry (Italian, Portuguese, Spanish and Indigenous), the decision to focus my research career on Indigenous Canadian and Brazilian literatures has been a hard task, since the academic system is considered part of what Gerald Vizenor calls "Cultural Word Wars between Whites and Indians in the New 
Fur Trade" (1978, p. viii), and in this war, I would be definitely positioned as someone who represents the Whites who recreated the New Fur Trade according to their rules. In his article "Is another cosmopolitics possible?", Mario Blaser calls attention to this issue when he addresses the difficulties and the dangers involved in the attempts to address and/ or represent the viewpoint of subjects that inhabit a different cosmovision, as it always involves a process of translation.

I believe it is crucial to start this article asserting my position as an outsider when addressing Cree and Munduruku cosmovisions. Therefore, my comparison of Tomson Highway's literary project to Daniel Munduruku's follows Eduardo Viveiros de Castro's concept of translation as a progressive project to compose a factual reality out of matters of concern and care in search of a common ground, yet being aware of the gaps and inconsistences involved in any comparative approach in which diverse cosmovisions are approximated. My main objective is to approximate Canadian and Brazilian experiences and to address the singular role that Highway and Munduruku assume in the literary histories of their countries as representative Indigenous writers and intellectuals. To achieve this goal, I align myself with Gerald Vizenor and Davi Kopenawa's ideas to construct a concept of linguistic and transcultural activism. In his preface to Wordarrows: Indians and whites in the New Fur Trade (1978, vii), Anishinabe writer and critic Gerald Vizenor compares the arrowmaker to the wordmaker, saying that the wordmaker shapes his words in the oral tradition with the same familial dedication that the traditional tribal arrowmaker turns his arrows on his teeth. Vizenor addresses these two concepts to highlight the importance of literary activism, in which the writer becomes the wordmaker that survives in the "word wars" when he recovers and translates his oral tradition and sacred memories into the written text.

This awareness about the role of Indigenous writers as wordmakers is also present in the book The falling sky: words of a Yanomani shaman (2013), by the Yanomami shaman Davi Kopenawa from Brazil and the French anthropologist Bruce Albert. This collaborative translation and publication is a defense of oral tradition and the power of the spoken word, which brought the Yanomami cause to international attention. Kopenawa asked Albert to help him "draw his words" in a book, setting his spoken words on paper 
(which he calls "image skins" or "paper skins") in the white man's language ("ghost talk") to spread them throughout the world (p. 11-13). From their different cultural and historical positions, Vizenor and Kopenawa address the importance of Indigenous literary and political activism.

While Indigenous writers approach local questions related to the recovery and empowerment of their cultural traditions, they also align themselves with political issues in a global scale, such as the protection of environment and resistance to racism and violence against women, which also emphasizes the transcultural dimension of their literary projects. For this text, my focus is on how Highway and Munduruku "give back the colonial gaze" in their literary works. As wordmakers, they use their arrows to create a transcultural poetics and act as cultural agents in order to transform and resist colonial dominant cultural practices.

In Canada, Tomson Highway is an acclaimed playwright, novelist and musician. He writes and has already published some of his plays in three languages: Cree (his mother tongue), French, and English. At the same time that he encourages the translation of his literary works into many different languages in the world, he is also committed to the empowerment of the Cree language. He has written the libretto to the Cree Opera - Pimoteewin (The Journey), and one of his most recent projects is the Montréal Symphony Orchestra presentation of Chaakapesh, The trickster's quest (2018), which encompasses ritual, dance, and an ode to the Earth, and is a new chamber opera based on Cree legend. Highway has also contributed to literary studies with the Charles R. Bronfman Lecture Comparing mythologies (2003), and has published the literary history From oral to written: A celebration of Indigenous Literature in Canada, 1980-2010 (2017).

His play The (post)mistress (2013) is a great example of how he is committed to transcultural literary activism. Marie-Louise Painchaud is the main character and the trickster in the play. She is the postmistress at the post office in Lovely, a small town in a farming community, in francophone Northern Ontario. The monologue by MarieLouise has two acts, in which she tells the audience the stories of the local inhabitants by reading their letters through the envelopes. Only in the end of the play we understand 
she can do that because she is materially dead, but in a spiritual dimension she acts as this messenger between the material and spiritual realms.

What is singular in this play is how Highway describes Canada and Canadians as part of a transcultural reality in which English, French and Cree are intertwined and Western and Indigenous cosmovisions are integrated. Marie-Louise has franconphone and Indigenous ancestries, since her great-grandfather, Lucien Boulanger, married a Cree woman. Moreover, she strongly inherited Cree culture so that she becomes a spiritual entity - the trickster, and continues to interfere in the material world.

As we observe in Highway's literary works in general, in The (post) mistress the trickster is a figure that tries to resist the colonial violence that permeates the relationship between Indigenous and non-Indigenous subjects and cosmovisions. His strategy can be compared to the anthropophagic ideas defended by the Brazilian Modernist movement, especially in Oswald de Andrade's Anthropophagic Manifesto (1928), when the Brazilian writer discusses the meaning of anthropophagy as the discursive strategy of absorption of the sacred enemy in which the anthropophagic literary text absorbs the culture of the enemy (online source). In the article "In the rhythm of Cree Samba: transculturality and decolonization in Tomson Highway's theatre" (2017), I have already analyzed how Highway incorporates his trips to South America and Brazilian culture in his composition of a Cree samba in The (post)mistress. My point, in this article, is to address the presence of Brazilian subjects and Brazilian culture as literary activism, since Cree co-opts Brazilian samba to survive in an anthropophagic and trickster discourse.

Besides the composition of a Cree samba, Highway also mentions Brazil in the ironic depiction of Sylvie Labranche's Brazilian lover, who writes in Cree. His name is Barbaro Botafogo and he is a linguist who specialized in Indigenous languages and, according to Marie-Louise, "came to Canada to study the Indians though, myself, I have no idea why the Indians have to be studied, but anyway" (2013, p. 5-6). Trickster MarieLouise resists the presence of the Brazilian researcher, who could be considered a threat, since his attitude might replicate the colonial enterprise in transforming Indigenous peoples and cultures into objects of scientific study. 
The process of diving into Indigenous Canadian literatures made me look back to Brazil to research about the Indigenous literary works that have been published lately. The writers that started to publish their literary works in Brazil belong to the Brazilian Indigenous Movement, which, according to Daniel Munduruku (2012, p. 11), was created as part of the social events that took place in the $1970^{2}$. Their works recover the function of traditional storytelling to reaffirm Indigenous identities and resist Eurocentric paradigms. Indigenous writers contribute to the innovation of literary genres and Brazilian literature, as well as they assume the role of spokespeople in their defense of Indigenous culture and political rights.

Lynn Mario de Souza (2004, p. 9) has argued about the multiple practices that characterize Indigenous writing in Brazil. He mentions several Amazonian cultures, like the Kashinawa, which are cultures of vision, so that writing has the function of translating vision to create knowledge. He also analyzes how some Indigenous authors have written texts in a Western literary format to be published and circulate as written stories (2003). According to him, Daniel Munduruku belongs to this group of writers who declare themselves Indigenous, but have migrated to national urban centers and integrated themselves into the mainstream culture, in a sense that they write to a dominant nonindigenous culture (2003, p. 135).

More than a decade has passed since de Souza published those fundamental texts to map Indigenous writing in Brazil, and today Daniel Munduruku is considered a central figure in Indigenous Literature. He left the Munduruku community in Para (North of Brazil) when he was fifteen years old and moved to São Paulo, the most important metropolitan center in the country. He graduated in Philosophy and got his Ph.D. in Education at the University of São Paulo. He was also a Post-Doctoral research fellow in Literature at the Federal University of São Carlos, in the state of São Paulo. Munduruku is an award winner children's literature writer who has published more than forty children's books. He has written one novel and some narrative books in which he recovers traditional storytelling as he rewrites Brazilian history, such as The Karaiba: $a$ story about pre-Brazil (2010) and Chronicles of São Paulo: an Indigenous Perspective $(2004)^{3}$. He has also created a blog called "Mundurukando" and a Youtube channel. 
Chronicles of São Paulo presents the city of São Paulo from the perspective of an Indigenous narrator that has moved from the North to the largest city in the Southeast of Brazil. The narrator describes São Paulo from his Indigenous perspective as he identifies the ancestral roots of the city through the names of important sites and neighborhoods. Each chapter tells the story of one place, such as Ibirapuera Park or Butantã neighborhood, and the last chapter tells about the first inhabitants of the place the Guarani people. The narrator/storyteller makes the city his own by showing through the stories he tells how he belongs to this physical space that was Indigenous much before the Portuguese colonizers arrived.

Munduruku's choice to name his book by the genre Chronicles shows how his narrator appropriates a narrative genre that was typical of colonial travel narratives. The imperial eyes of travel writing that Mary Louise Pratt (CUNHA, 2014, p. 79) identifies in the colonizers' transcultural experience are replaced by the Indigenous eyes of a migrant storyteller. Such a complex transcultural movement dislocates the Indigenous perspective from the margins to the center, as it combines the narratives of the past that are associated with Indigenous peoples to the present and the future in which Indigenous people live in hegemonic Western culture.

The narrator/storyteller assumes the role of the wordmaker and reminds the reader that "we don't see only with our eyes, but also with our tongue. It is what gives us taste and knowledge, and here in our land there used to be many tastes and knowledges that enrichened our people" (2010, p. 55). Munduruku recovers the origins of the word Butantã, which is the neighborhood where the Butantan Institute is located, a biologic research center world-renowned for its collection of venomous snakes. The narrator recovers the story his father told him to explain why snakes are dangerous. In Munduruku mythology, the reptiles were once the only owners of the night, so that many tricks were necessary to convince them to share the night with humans. That is why the snakes were "magic beings, which were always trying to take back from humans the night that was once theirs" (2010, p. 38). The storyteller recovers his fearful memories of the snake, as well as he identifies himself with this magic entity. When he tells about his first job as a teacher in São Paulo, he compares himself to the serpents that crawl and disguise themselves under 
the wood planks in search of food, since they transform themselves in order to survive: "In my serpent way, searching for the planks in which I could find food and raw material for my flute, I developed my way of seeing São Paulo to take from it whatever is possible to keep the sky in balance, avoiding its self-destruction" (2010, p. 43)

In Chronicles of São Paulo, Munduruku recognizes the role of the Indigenous writer as addressed by Vizenor and Kopenawa: a "word warrior", a wordmaker that shapes his words in the oral tradition to resist colonial discourses. The narrator stresses that he became "a passer-by and turned the boat into train, the bow into words, the forest into plank, the darkness into electric light, the reserve into the city. I did not leave my territory to go to the city. I transformed the city into my territory" (MUNDURUKU, 2010, p. 43).

It is notable that, in both Highway's The (post)mistress and Munduruku's Chronicles of São Paulo, transcultural movement and transformation are part of the survival of Indigenous subjects and their cultures. In the quotation above, the narrator of Munduruku's narrative defends his insertion into the metropolitan center as a form of appropriation of Western culture, in a sense that his presence in the city of São Paulo "indigenizes" the urban space to make it his own. When he compares himself to a serpent in constant transformation, he also reminds us of trickster narratives of the anaconda spirit in the Amazon region in which the change of skin is a way to survive and resist (de Souza, 2001; Cunha, 2014; 2017). In Highway’s play, it is Marie-Louise's trickster act of transgression by reading the letters through the envelopes that shows the survival of Cree knowledge when in contact with English, French and Latin American cultures.

Transformation and survival are in the nature of the trickster figure, as Lee Maracle points out in Memory Serves: Oratories (2015). In the chapter "Understanding Raven", she states that to her the role of Raven is "transformation and agency. And that, as Salish mythmakers hold, is the point of story" (p. 88). It is in this perspective that I acknowledge tricksterism in Tomson Highway and Daniel Munduruku's literary texts. The main characters of both The (post) mistress and Chronicles of São Paulo are in constant movement and transformation - from North to South in Munduruku's narrative; whereas the protagonist of Highway's play transcends not only geographical and cultural borders, but also mythological and cosmogonic ones by her movement from the spiritual 
to the material world. Despite the differences that characterize the two literary texts and Indigenous cosmovisions, what we see in common is this commitment to a trickster-shift of resistance and survival as a political statement, or what I call transcultural activism.

\section{Referências}

ANDRADE, Oswald de. Anthropophagic Manifesto. Revista de Antropofagia [Journal of Anthropophagy], São Paulo, 1 (1), May 1928. Translated into English by Maria do Carmo Zanini in 2006. Available at: http://sibila.com.br/english/anthropophagic-manifesto/2686. Access: May 24, 2018.

BLASER, Mario. Is Another Cosmopolitics Possible? Cultural Anthropology, Vol. 31, Issue 4, pp. 545-570.

CUNHA, Rubelise da. O 'arco em palavra': a reinvenção do presente nas crônicas de Daniel Munduruku. Revista Pontos de Interrogação: Arquivos e testemunhos sobre língua, cultura e modos de vida indígena, v. 4, n. 2, 2014, p. 71-84.

. In the Rhythm of Cree Samba: transculturality and decolonization in Tomson Highway's Theatre. Canada and Beyond: a Journal of Canadian Literary and Cultural Studies, v. 6, 2017, p. 45-53.

HIGHWAY, Tomson. Comparing Mythologies. Ottawa: University of Ottawa Press, 2003.

KOPENAWA, Davi; ALBERT, Bruce. The Falling Sky: Words of a Yanomami Shaman. Nicholas Elliott and Alison Dundy, trans. Cambridge: Harvard UP, 2013.

MARACLE, Lee. Understanding Raven. Memory serves: oratories. Smaro Kamboureli, (Ed.) Edmonton: NeWest Press, 2015, p. 85-104.

MUNDURUKU, Daniel. Crônicas de São Paulo. São Paulo: Callis, 2004.

. O caráter educativo do movimento indígena brasileiro (1970-1990). São Paulo: Paulinas, 2012.

PRATT, Mary Louis. Imperial eyes: travel writing and transculturation. London: Routledge, 1992.

SOUZA, Lynn Mario Trindade Menezes de. As visões da anaconda: a narrativa escrita indígena no Brasil. Semear (PUCRJ), Rio de Janeiro, v. 7, p. 223-236, 2002. http:// www.letras.puc-rio.br/unidades\&nucleos/catedra/revista/7Sem_16.html. Access on May 19, 2018.

. Que história é essa? A escrita indígena no Brasil. In: SANTOS, Eloína Prati dos (Org.). Perspectivas da literatura ameríndia no Brasil, Estados Unidos e Canadá. Feira de Santana: UEFS, 2003. p. 123-137.

. Remapping writing: Indigenous writing and cultural conflict in Brazil. English Studies in Canada, v. 30, n. 3, p. 4-16, 2004. 
VIVEIROS DE CASTRO, Eduardo. Perspectival Anthropology and the Method of Controlled Equivocation. Tipiti: Journal of the Society for the Anthropology of Lowland South America 2, no. 1: 3-22, 2004. http://digitalcommons.trinity.edu/tipiti/vol2/iss1/1.

VIZENOR, Gerald. Wordarrows: Indians and Whites in the new fur trade. Minneapolis: University of Minnesota Press, 1978.

\section{Notas}

${ }^{1}$ Associate Professor, Center for Canadian Studies (NEC-FURG), Federal University of Rio Grande (FURG), Rio Grande do Sul, Brazil, rubelisecunha@furg.br.

${ }^{2}$ According to Daniel Munduruku, the Indigenous peoples joined the social movements in the defense of democracy that developed during dictatorship in the 1970s through their participation in assemblies of Indigenous leaders and chiefs. It is from this insertion in social movements that a Pan-Indigenous consciousness emerged, since they realized there were similar issues among the different Indigenous groups and were able to generate concrete actions in defense of their rights.

${ }^{3}$ My translation into English to the titles of Daniel Munduruku's books: O Karaíba: uma história do pré-Brasil (2010) e Crônicas de São Paulo: um olhar indígena (2004).

${ }^{4}$ All quotations from Daniel Munduruku's book have been translated into English by the author of the article. ${ }^{6}$ Referencia-se o texto Página gravada, de Raquel Stolf, em que são abordadas relações entre disco de artista e livro/publicação de artista investigando-se relações entre texto e som, trânsitos entre palavra e silêncio, entre processos de escrita e situações de escuta e leitura, articulados em alguns trabalhos artísticos que consistem em publicações sonoras e em outras publicações de artista. Disponível em:

$<$ http://periodicos.unespar.edu.br/index.php/sensorium/article/view/1020>. Acesso em: 15 mar. 2017. 